\title{
Peran Lembaga Keuangan Syariah dalam Pemberdayaan UMKM di Indonesia
}

\author{
Singgih Muheramtohadi \\ UIN Walisongo Semarang \\ singgih.muheram@gmail.com
}

\begin{abstract}
Syariah Financial Institution means that the financial institution is run based on the Islamic teaching that refers to Qur'an and the Sunnah. Practically, it began in early history of islam, then was developed into Syariah Financial Institution. So, the purpose of Syariah Financial Institution is not merely for profit orientation. Further, it should be in accordance with Islamic value and the human philantrophy. Most of Syariah Financial Institution's financing is for busines sector and its ability to reach the micro business, that can't be done by commercial banks. The financing for small business is funded by islamic institutions due to Grameen Bank effect. Previously, Grameen Bank was built in mid-decade of 1970. The Financing of Syariah Financial Institution, in any sort, including cooperative union or BMT (Baitul Maal wa Tamwil), increased overtimein both Institution Revenue and the Financing Rate. According to Financial Service Authority, most of financing of Syariah Banking is for the Micro, Small, Medium Enterprises that is very important for the nation economy, because it is engaged in the real sector of economy. And the other characters of the Micro, Small, MediumEnterprises in Indonesia are holdingthe honesty ethics and resistante to the crisis. They are the strengths of UMKM which must be considered to make the decision by the government or the Financial Institutions.
\end{abstract}

Keywords: Sharia Financial Institution; Empowerment; UMKM

\begin{abstract}
Abstrak
Lembaga Keuangan Syariah (LKS) berarti badan yang bergerak di bidang keuangan yang dilandaskan pada ajaran Islam yang bersumber pada al Qur'an dan As Sunnah. Praktek ini sudah terdapat pada sejarah awal Islam, dan asas moralitas Islam dikembangkan dalam bentuk LKS. Sehingga, tujuan dari LKS tidak semata Profit Oriented, melainkan terdapat unsurunsur keislaman dan kemanusiaan di dalamnya. Lembaga Keuangan syariah sebagian besar pembiayaannya diperuntukkan kepada sektor usaha, dan punya kemampuan untuk menjangkau usaha mikro, Sesuatu yang jarang dilakukan oleh pihak perbankan konvensional. Pembiayaan kepada UMKM ini tidak lepas juga dari pengaruh Grameen Bank sebelumnya, yang telah berdiri sejak medio 1970-an. Pembiayaan Lembaga Keuangan Syarah, baik dalam wujud Bank, Koperasi Simpan Pinjam maupun BMT mengalami peningkatan dari waktu ke waktu. Baik itu dari segi omzet LKS maupun tingkat pembiayaan nya. Berdasarkan data dari Jasa Otoritas Keuangan sebagian besar dari pembiayaan tersebut disalurkan kepada UMKM. Pembiayaan UMKM sangat penting dalam perekonomian nasional, karena bergerak di sektor riil. Karakteristik UMKM adalah sebagai usaha menengah ke bawah, pada umumnya dikelola dengan etika kejujuran masih dipegang kuat, serta relatif lebih kuat ketika dihadapkan pada
\end{abstract}


krisis. Inilah yang jadi potensi UMKM yang harus diperhatikan dalam mengambil keputusan publik, baik itu oleh Pemerintah maupun Lembaga Keuangan (perbankan).

Kata Kunci: Lembaga Keuangan Syariah; Pemberdayaan; UMKM

\section{PENDAHULUAN}

Hubungan antara Lembaga Keuangan Syariah (LKS) dan UMKM sangat penting untuk diperhatikan. Hal ini karena UMKM merupakan usaha yang dikelola oleh pengusaha kecil, dan dengan modal kecil, tetapi mempunyai kontribusi besar sebagai salah satu tiang penyangga perekonomian Indonesia. Di sisi lain, mereka adalah usaha yang rentan karena kurangnya akses terhadap permodalan, kecilnya daya produksi yang dihasilkan maupun pangsa pasar yang relatif sempit.

Permodalan adalah salah satu problema utama UMKM. Di sisi lainnya, Lembaga Keuangan Syariah (LKS), tidak hanya berorientasi pada pencarian profit semata, melainkan juga memiliki sisi kemanusiaan, yaitu melakukan pemberdayaan kepada para pengusaha UMKM. Tulisan ini mendeskripsikan hubungan simbiosis mutualisme antara Lembaga keuangan Syariah dengan UMKM.

Beberapa hal yang hendak diangkat oleh tulisan ini adalah pengertian LKS, perkembangan LKS, bentuk pemberdayaan yang dilakukan terhadap UMKM serta potensi kerjasama antara LKS dengan UMKM.

\section{Lembaga Keuangan Syariah \& UMKM}

\section{Pengertian}

Lembaga Keuangan Syariah adalah badan usaha yang kegiatannya dibidang keuangan yang didasarkan prinsip-prinsip syariah (Laksmana, 2009: 10) atau dengan kata lain bersumber dari ayat-ayat Al-Quran dan As-Sunnah yang berkaitan dengan etika bermuamalah dan transaksi ekonomi, baik dalam bentuk bank maupun non bank. Dalam Islam, tidak semua transaksi ekonomi dilarang, demikian juga sebaliknya, tidak semua transaksi ekonomi diperbolehkan. Hal yang terlarang dalam Islam, salah satunya adalah riba. Riba adalah penetapan kelebihan atau tambahan jumlah pinjaman yang dibebankan kepada si peminjam, atau dalam dunia perbankan diistilahkan dengan 'bunga'.

\section{Landasan Pelarangan Riba diLembaga Keuangan Syariah (LKS)}

Salah satu permasalahan yang dihadapi oleh lembaga keuangan, baik itu Bank maupun Koperasi Simpan Pinjam, selama ini hanya 'menggantungkan' keuntungan dari bunga. Bank manapun menetapkan berapa tinggi suku bunganya. Misalnya, sebuah perbankan menetapkan $10 \%$, jika seorang peminjam menerima pinjaman 100 juta rupiah, maka ia harus mengembalikan 110 juta dalam satu tahun. Jumlah 10 juta ini lah yang dianggap sebagai riba dalam Islam. Larangan riba dapat dilihat dari ayat berikut ini: "Hai orang-orang yang beriman, janganlah kamu memakan riba dengan berlipat-ganda dan bertaqwalah kamu kepada Allah supaya kamumendapat keberuntungan.” (Q.S. Ali Imran: 130).

Pada ayat lainnya Allah berfirman;"Hai orang-orang yang beriman, bertaqwalah kepada Allah dan tinggalkan sisa-sisa (dari berbagai jenis) riba jika kamu orangorang yang beriman. Maka jika kamu tidak mengerjakan (meninggalkan sisa riba) maka 
ketahuilah, bahwa Allah dan rasul-Nya akan memerangimu. Dan jika kamu bertaubat (dari pengambilan riba), maka bagimu pokok hartamu; kamu tidak menganiaya dan tidak pula dianiaya." (Q.S. Al Baqarah: 278-279)

Kedua ayat tersebut diatas melarang keras pinjam meminjam uang berdasarkan sistem riba, atau penambahan di luar hutang pokok. Asbabun Nuzul Surat al Baqarah: 278- 279 berdasarkan atas sebuah kejadian, yaitu berhutangnya Bani Mughirah kepada Bani Amr. Setelah Bani Mughirah berpindah ke Islam, mereka tidak diperkenankan untuk melakukan transaksi pinjam meminjam berdasarkan riba, baik itu hutang mereka kepada pihak lainnya (termasuk Bani Amr), maupun piutang yang mereka miliki. Atas perselisihan ini, maka lewat surat menyuratnya dengan pemimpin Mekkah (setelah peristiwa Fathul Makkah), menurut Ibn Jarir Ath Thabari dalam bukunya Tafsir Ath Thabari hal seperti diatas, Rasulullah menyuruh hanya membayarkan hutang pokoknya, jika ditolak, maka Rasulullah siap mengultimatum perang. (Ibn Jarir Ath Thabari: Tafsir Ath Thabari Vol. IV).

Idealnya, segala transaksi yang tidak diperbolehkan dalam Islam tidak dilakukan dalam sistem perbankan ini. Bunga adalah salah satu sumber pemasukan utama bagi perbankan, dan bunga dalam kredit hukumnya haram. Pertanyaannya adalah bagaimana jika sebuah bank menghapus bunga dari sistem operasionalnya? Dari mana mereka memperoleh penghasilan selain dari cara tersebut?

Islam menawarkan sistem bagi hasil yang salah satunya disebut dengan mudharabah, yaitu akad pembagian keuntungan yang dilakukan antara pemberi modal dan penerima modal untuk usaha, dan pembagian dilakukan berdasarkan keuntungan usaha.Mudharabah ini secara bahasa artinya adalah kerjasama, dalam hal ini adalah kerjasama permodalan (Antonio, 2001: 95)

Praktek mudharabah merupakan praktek yang dilakukan oleh Rasulullah sebelum diangkat menjadi Nabi, sebagaimana yang ia lakukan bersama Siti Khadijah. Siti Khadijah menyumbang modal besar untuk melakukan perjalanan dagang Rasul, sedangkan Rasulullah sendiri menyumbang tenaga dan keahliannya dalam berdagang. Keuntungan dari keduanya dibagi secara bersama. Jika merugi, maka merugi secara bersama-sama, jika untung maka keuntungannya dibagi diantara keduanya. Inilah yang membedakan dengan sistem riba. Dalam riwayat lainnya, Khalifah kedua Umar Ibn Khatab, pernah menginvestasikan harta anak yatim kepada para saudagar (Lewis \& Algaoud, 2001: 14).

\section{Fungsi Lembaga Keuangan Syariah}

Keberadaan lembaga keuangan sangat dibutuhkan di berbagai tempat karena tidak hanya sebagai tempat menyimpan uang semata, melainkan juga sebagai tempat dimana modal terhimpun dan dapat diakses. Fungsi lembaga keuangan syariah sama seperti lembaga keuangan lainnya, yaitu;

\section{a. Penghimpunan Dana}

Menghimpun dana dari masyarakat dalam bentuk tabungan. Dalam fiqh Islam dikenal dengan barang wadi'ah, dan dalam praktek yang dilakukan oleh lembaga keuangan syariah dalam bentuk Tabungan Wadiah. Tabungan Wadiah dapat digunakan oleh pengelola keuangan, untuk diinvestasikan pada usaha, dengan izin pemiliknya, atau biasa disebut dengan wadi'ah yad dhamanah. Pihak Lembaga Keuangan Syariah (LKS) sebagai pihak yang dititipi barang, dapat menggunakan barang terse- 
but untuk dikelola ke sektor yang lebih produktif. Wadi'ah dalam sistem Islam dapat berbentuk apa saja, baik dalam bentuk uang, emas, perak, dan berbagai barang yang berharga lainnya. Praktek wadi'ah dapat dijumpai dalam sejarah awal Islam, dan menurut para ulama hal ini diperbolehkan. Selain produk wadiah, penghimpunan dana oleh LKS dapat dilakukan dengan prinsip mudharabah dan ijarah. (Sholihin, 2010: 291). Bahkan pada prakteknya saat ini, mayoritas produk penghimpunan dana yang laku di masyarakat adalah produk yang menggunakan prinsip mudharabah. Hal ini disebabkan karena produk yang menggunakan prinsip mudharabah dianggap lebih menguntungkan karena memberikan bagi hasil untuk para penabung secara berkala. Berbeda dengan tabungan dengan prinsip wadiah yang hanya memberikan bonus yang belum tentu ada di setiap waktu.

\section{b. Penyaluran Dana ke Masyarakat}

Setelah dana dari masyarakat dalam bentuk tabungan telah terkumpul, maka LKS kemudian menyalurkannya kembali kepada masyarakat yang membutuhkan. Dalam sistem perbankan Islam, idealnya dana tersebut disalurkan hanya kepada pihak yang memiliki usaha dan untuk pengembangan usaha. Sedangkan untuk kebutuhan non usaha, seperti untuk pembayaran SPP, maka akadnya hanya pinjam tanpa adanya bagi hasil ataupun bunga. Dalam sistem perbankan Islam simpan pinjam ini, sebagaimana telah disebutkan di atas, dinamakan dengan qirodh atau mudharabah. Selain itu, perbankan syariah juga melaksanakan pelayanan jasa lainnya, seperti $w a-$ kalah, qardh al hasan, dan sebagainya.

\section{c. Fungsi Sosial Kemasyarakatan}

Yaitu menghimpun dana dari masyarakat dalam bentuk Zakat, Infaq atau Sedekah (Ziswaf), kemudian menyalurkannya kepada pihak yang membutuhkannya, tanpa mengharapkan keuntungan ataupun imbalan (Ikit, 2015: 47). Lembaga keuangan Islam, sebagaimana aturan perundang-undangan, berhak menghimpun dana zakat, infaq, dan shodaqoh dari masyarakat untuk disalurkan kepada pihak yang membutuhkannya. Perannya hampir sama dengan pihak 'amil', dimana ketentuannya mendapatkan hak 1/5 dari jumlah dana ziswaf yang dihimpun. Fungsi sosial inilah sebagai salah satu pembeda LKS dengan lembaga keuangan perbankan umum.

\section{Pengertian UMKM}

UMKM adalah singkatan dari Usaha Mikro, Kecil, dan Menengah. Sehingga UMKM terdiri dari tiga bentuk usaha berdasarkan skalanya, yaitu meliputi; Usaha Mikro, Usaha Kecil dan Usaha Menengah. Berikut adalah pengertian dari ketiganya didasarkan Undang-undang;

a. Usaha Mikro adalah usaha produktif milik orang perorangan dan/atau badan usaha perorangan yang memenuhi kriteria Usaha Mikro sebagaimana diatur dalam Undang-Undang ini. Kriteria aset: Maksimal 50 Juta, kriteria Omzet: Maksimal 300 juta rupiah.

b. Usaha Kecil adalah usaha ekonomi produktif yang berdiri sendiri, yang dilakukan oleh orang perorangan atau badan usaha yang bukan merupakan anak perusahaan atau bukan cabang perusahaan yang dimiliki, dikuasai, atau menjadi bagian baik langsung maupun tidak langsung dari usaha menengah atau usaha besar yang me- 
menuhi kriteria Usaha Kecil sebagaimana dimaksud dalam Undang-Undang ini. Kriteria asset: 50 juta - 500 juta, kriteria Omzet: 300 juta - 2,5 Miliar rupiah.

c. Usaha Menengah adalah usaha ekonomi produktif yang berdiri sendiri, yang dilakukan oleh orang perseorangan atau badan usaha yang bukan merupakan anak perusahaan atau cabang perusahaan yang dimiliki, dikuasai, atau menjadi bagian baik langsung maupun tidak langsung dengan Usaha Kecil atau usaha besar dengan jumlah kekayaan bersih atau hasil penjualan tahunan sebagaimana diatur dalam Undang-Undang ini. Kriteria aset: 500 juta - 10 Miliar, kriteria Omzet: $>2,5$ Miliar - 50 Miliar rupiah(UU No. 20 Tahun 2008).

\section{Pemberdayaan UMKM}

Lembaga Keuangan Syariah dapat menjadi lembaga keuangan yang memiliki fungsi untuk melakukan pemberdayaan. Pemberdayaan, merupakan istilah khas dalam dunia NGO (Non Government Organization) atau dikenal dengan LSM. Dalam istilah asing (bahasa Inggris) dinamakan dengan empowerment, yang secara sederhana didefinisikan dengan penguatan potensi manusia, baik individu maupun masyarakat, agar memperoleh inisiatif dan kendali lebih besar terhadap bidang kehidupan mereka sendiri (Wrihatnolo \&Dwidjowijoto, 2007: 180). Dalam obyek pemberdayaan, hal ini adalah UMKM.

UMKM memiliki karakteristik sendiri yang berbeda dengan perusahaan berskala luas. Mereka pada umumnya memiliki karakter mandiri tanpa memiliki relasi luas, atau berada di bawah naungan grup usaha. Karakteristik lain dari UMKM adalah menggunakan teknologi rendah atau sederhana, bahkan usaha mikro sering menggunakan teknologi manual. Sebagai contoh, di wilayah Bantul, proses pembuatan emping banyak dikerjakan oleh ibu-ibu, berdasarkan wawancara penulis dengan para pengelola usaha emping, mereka hanya menggunakan peralatan apa adanya, dan hanya memproduksi beberapa kilo, dan keuntungan bersihnya masih di bawah Rp. 30.000,- per hari.

Keunikan UMKM dibandingkan dengan perusahaan berskala luas, yaitu pangsa pasar yang lebih sempit. Orientasinya hanya terfokus pada pasar lokal atau lokasi sekitarnya. Modal usaha UMKM sangat terbatas dan akses ke bantuan permodalan juga relatif susah didapatkan, padahal mereka pada umumnya juga sangat membutuhkan modal untuk mengembangkan usahanya. Mereka membutuhkan banyak bahan dan alat yang mampu meningkatkan jumlah komoditas yang mereka hasilkan.

Dengan demikian, kelebihan memberikan modal kepada sektor UMKM adalah;

1. Faktor kemanusiaan adalah hal yang penting untuk diperhatikan. Bahwa UMKM (Usaha Mikro, Kecil, dan Menengah) pada umumnya adalah pihak yang benarbenar membutuhkan bantuan permodalan dan seharusnya diberikan perhatian lebih intensif.

2. Mereka bergerak di bidang riil, baik berupa barang maupun jasa. Pinjaman yang mereka perlukan tidak untuk usaha non riil, seperti spekulasi bursa saham. Pembiayaan sektor riil sangat penting, karena sektor inilah kekayaan negara dalam arti sesungguhnya.

3. Pengelola UMKM pada umumnya masih berpijak pada etika bisnis dan moralitas. Mereka pada umumnya lebih menghormati akad (perjanjian) pinjam meminjam 
daripada umumnya para pengusaha besar.

Usaha pemberian modal kepada UMKM lewat lembaga keuangan mikro, dipopulerkan oleh Muhammad Yunus. Ia memberikan pinjaman kepada kelompok usaha mikro yang tidak tersentuh oleh lembaga kredit pada waktu itu di Bangladesh. Di sini, peran lembaga keuangan tidak hanya sebatas lembaga profit semata, melainkan juga sebagai tugas kemanusiaan, yaitu menguatkan pihak yang lemah melalui pinjaman usaha kepada mereka.

\section{Perkembangan Pembiayaan Lembaga Keuangan Syariah terhadap UMKM di Indonesia}

Sebagaimana disebutkan di atas, bank punya peran besar, dalam menghimpun dana dari masyarakat dan kemudian menyalurkannya sebagai modal usaha, sehingga tercipta pertumbuhan ekonomi. Hal ini menggambarkan betapa lembaga keuangan berperan sangat penting dalam pembangunan ekonomi negara. Dengan modal, dapat mengubah benda yang tidak bermanfaat menjadi benda yang bermanfaat. Contohnya adalah sebuah lahan kosong, ia hanya memiliki potensi, tetapi tidak dapat diambil manfaat darinya. Lahan tersebut baru bisa menjadi produktif jika ada modal. Misalnya mengubah lahan kosong tersebut menjadi area perkebunan atau bangunan ruko.

Permasalahannya adalah bahwa untuk akses modal tersebut relatif sulit dilakukan oleh usaha kecil atau mikro, dikarenakan beberapa hal, seperti;

1. Sistem administrasi bank yang berbelit-belit dan mensyaratkan adanya jaminan yang sepadan dengan uang yang dipinjamkan.

2. Pelaku usaha kecil pada umumnya adalah kelompok akar rumput dari masyarakat yang kurang familiar dengan bahasa-bahasa teknis perbankan.

Di sinilah peran lembaga keuangan syariah ke depannya, yaitu kemampuan menjangkau masyarakat bawah tanpa adanya mekanisme syarat yang terlalu berat dan bahasa yang lebih mudah dipahami.

Sebenarnya jumlah dana yang dihimpun oleh lembaga keuangan di Indonesia relatif besar, dan jika semuanya dialokasikan kepada UMKM maka akan lebih dari cukup untuk lebih memberdayakan UMKM tersebut. Sebagaimana yang dilansir dari Berita Satu dengan Judul "Total Aset Lembaga Keuangan Capai Rp. 7.800 Triliun rupiah".Dari Jumlah total Rp. 7.800 triliun total aset keuangan, porsi yang dimiliki oleh lembaga keuangan syariah hanya 3,49 persen, sedangkan jumlah pembiayaan perbankan di sektor UMKM terus mengalami pertumbuhan. Pada tahun 2005 sebesar 633,945 triliun, menjadi 737,355 triliun di tahun 2009, dan pada tahun 2010 mengalami kenaikan sejumlah 926,782 triliun (Situs Bank Mandiri Syariah).

Peningkatan aset dan pembiayaan untuk UMKM tidak hanya terjadi pada bank konvensional, melainkan juga pada LKS. Misalnya jumlah Bank Umum Syariah meningkat dari 2 bank di tahun 2000, meningkat menjadi angka 11 di tahun 2012. Aset yang dimiliki oleh lembaga keuangan syariah pun juga mengalami kemajuan dari masa ke masa. Pada tahun 2012 tercatat jumlah asetnya 149 triliun, dengan total penghimpunan dana dari pihak ketiga sejumlah 116 triliun dan total pembiayaan sebesar 106 triliun. Jumlah tersebut berkembang dari masa-masa sebelumnya. Terkait perkembangan lembaga keuangan syariah dapat dilihat dari tabel-tabel berikut ini: 
Tabel 1. Perbandingan Kinerja Perbankan antara Tahun 2000-2012

\begin{tabular}{lll}
\hline \multicolumn{1}{c}{ Indikator } & \multicolumn{1}{c}{ Tahun 2000 } & \multicolumn{1}{c}{ Tahun 2012 } \\
\hline Bank Umum Syariah & 2 & 11 \\
Unit Usaha Syariah & 3 & 24 \\
BPRS (Bank Pembiayaan & 79 & 155 \\
Rakyat Syariah) & & \\
Aset & 1.790 Miliar & 149.321 Miliar \\
Dana Pihak Ketiga & 1.029 Miliar & $?$ \\
Pembiayaan Yang Diberikan & 1.271 Miliar & 106.532 Miliar \\
\hline
\end{tabular}

Total aset perbankan syariah berkembang lebih besar dari tahun ke tahun. Berikut adalah perkembangan aset dari 2013 hingga 2016. Berdasarkan data terakhir perkembangan aset mencapai 356,50 triliun, sebagaimana dapat dilihat dari data Otoritas Jasa Keuangan 2017 berikut ini;

Tabel 2. Perkembangan Aset Perbankan Syariah

\begin{tabular}{cc}
\hline Tahun & Total Aset \\
\hline 2013 & 242,27 Triliun \\
2014 & 272,34 Triliun \\
2015 & 296,26 Triliun \\
2016 & 356,50 Triliun \\
\hline
\end{tabular}

Dilihat dari tabel-tabel diatas, maka terdapat peningkatan manfaat perbankan syariah, yaitu lewat pembiayaan yang diberikan. Dari 1.271 miliar di tahun 2000 meningkat ke angka 106.532 miliar pada tahun 2012. Pada umumnya pembiayaan yang dilakukan oleh perbankan syariah untuk tujuan pengembangan usaha (lewat mekanisme mudharabah dan musyarakah).

Mekanisme Pembiayaan mudharabah maupun musyarakah dapat digunakan untuk pembiayaan usaha dalam bentuk apapun, baik dalam bentuk manufaktur, pertanian, dan lain sebagainya selama tidak bertentangan dengan syariat Islam (misalnya tidak diperbolehkan dana dipakai untuk usaha pemotongan daging babi).

Pembiayaan perbankan syariah di Indonesia, berdasarkan data dari Otoritas Jasa Keuangan periode Februari 2017, tumbuh positif yaitu sebesar 16,22 persen atau sebesar 252,69 Triliun. Berdasarkan data yang didapat dari Otoritas Jasa Keuangan (OJK) Caturwulan ke III tahun 2016, jumlah pembiayaan untuk berbagai jenis sektor mengalami kenaikan hingga 222,175 triliun Rupiah dan kecenderungannya tetap meningkat dari tahun ke tahun. Hal ini dapat dilihat dan dibandingkan dengan tahuntahun sebelumnya. Pada tahun 2009, jumlah pembiayaan di berbagai sektor ekonomi sebesar 46,886 triliun, dan pada tahun 2013 meningkat menjadi 184,122 triliun. Berikut adalah tabel peningkatan jumlah pembiayaan dari tahun ke tahun berdasakan laporan Otoritas Jasa Keuangan September 2015. 
Tabel 3. Jumlah Pembiayaan

\begin{tabular}{cccccc}
\hline Tahun & 2009 & 2010 & 2011 & 2012 & 2013 \\
\hline Jumlah Pembiayaan & 46,886 & 68.181 & 102.655 & 147.505 & 184.122 \\
\hline
\end{tabular}

Pembiayaan tersebut meliputi berbagai bidang. Berikut adalah sektor ekonomi yang dibiayai oleh perbankan syariah berdasarkan pada Statistik Perbankan Syariah pada September 2016.

Tabel 4. Pembiayaan Bank Syariah berdasarkan Sektor Ekonomi

\begin{tabular}{lrr}
\hline Sektor Ekonomi & $\begin{array}{r}\text { Pembiayaan } \\
\text { (Milyar) }\end{array}$ & Porsi \\
\hline Pertanian, Perburuhan, Kehutanan & 7.830 & 3,52 \\
Perikanan & 1.379 & 0,62 \\
Pertambangan dan penggalian & 6.301 & 2,84 \\
Industri Pengolahan & 18.300 & 8,24 \\
Listrik, Gas dan Air & 7.204 & 3,24 \\
Konstruksi & 10.826 & 4,87 \\
Perdagangan Besar dan Eceran & 28.457 & 12,81 \\
Akomodasi dan PMM & 2.768 & 1,25 \\
Transportasi, Pergudangan dan & 11.293 & 5,08 \\
Komunikasi & & \\
Perantara Keuangan & 19.596 & 8,82 \\
Real Estate, Persewaan, \& Jasa & 10.297 & 4,63 \\
Perusahaan & & \\
Adm. Pemerintahan, Pertahanan dan & 263 & 0,12 \\
Jaminan Sosial & & \\
Jasa Pendidikan & 3.436 & 1,55 \\
Jasa Kesehatan dan Kesos & 2.723 & 1,23 \\
Kemasyarakatan dan sosbud lainnya & 4.613 & 2,08 \\
Jasa Perorangan & 338 & 0,15 \\
Badan Internasional dan lainnya & 1 & 0,00 \\
Kegiatan yang belum jelas & 1.537 & 0,69 \\
Rumah Tangga & 81.681 & 36,76 \\
Bukan Lapangan Usaha Lainnya & 3.330 & 1,50 \\
\hline TOTAL & 222.175 & 100 \\
\hline & &
\end{tabular}

Pada tabel di atas, sektor ekonomi rumah tangga dan perdagangan besar dan eceran, merupakan sektor ekonomi yang paling banyak dibiayai oleh perbankan syariah, dengan jumlah 36,76 persen dan 12,81 persen. Dilihat dari peruntukan usaha di atas, makamemenuhi porsi minimum pembiayaan UMKM Bank Indonesia yang sebesar 15 persen dari total pembiayaan.

Berikut adalah Tabel Pembiayaan UMKM, perbandingan antara posisi akhir di tahun 2015, dengan posisi pembiayaan UMKM dan non UMKM pada Agustus dan September 2016. 
Tabel 5. Pembiayaan UMKM

\begin{tabular}{lrrrr}
\hline \multirow{2}{*}{$\begin{array}{c}\text { Jenis Penggunaan dan Kategori } \\
\text { Usaha }\end{array}$} & Nov & Des & Ags & Sep \\
\cline { 2 - 5 } & 80.108 & 79.949 & 79.060 & 81.595 \\
1. Modal Kerja & 30.475 & 33.382 & 33.203 & 35.022 \\
a. UMKM & 2.413 & 2.275 & 2.343 & 2.475 \\
NPF & 49.633 & 46.567 & 45.857 & 46.573 \\
b. Bukan UMKM & 2.366 & 2.643 & 2.857 & 2.454 \\
NPF & 48.428 & 51.690 & 55.654 & 56.991 \\
2. Investasi & 16.323 & 16.909 & 17.659 & 17.910 \\
a. UMKM & 1.153 & 1.136 & 1.777 & 1.631 \\
NPF & 32.105 & 34.781 & 37.995 & 39.081 \\
b. Bukan UMKM & 1.609 & 1.189 & 1.371 & 1.318 \\
NPF & 80.588 & 81.357 & 85.739 & 96.420 \\
3. Konsumsi & 209.124 & 212.996 & 220.452 & 235.005 \\
\hline Total Pembiayaan &
\end{tabular}

$\mathrm{NPF}=$ Non Performing Financing (Pembiayaan Bermasalah).

Modal Kerja untuk UMKM pada Desember 2015 sebesar 79,949 triliun kemudian meningkat menjadi 81,595 triliun pada September 2016. Tetapi peningkatan jumlah pembiayaan Modal Kerja UMKM ini diikuti dengan peningkatan pembiayaan bermasalah, dari 2,275 triliun menjadi 2,475 triliun. Hal yang sama juga terjadi pada pembiayaan Investasi UMKM. Pada kurun waktu yang sama, Desember tahun 2015, sebesar 51,690 triliun, kemudian meningkat lebih dari 5 triliun, yaitu sebesar 56,991 triliun pada bulan September 2016. Kemudian, diikuti dengan peningkatan pembiayaan bermasalah (NPF/Non Performing Financing). Pada akhir tahun 2015 sebesar 1,189 triliun menjadi 1,631 triliun.

Pada tabel di atas, jumlah dana yang diperuntukkan kepada UMKM sangat besar, baik dalam bentuk modal kerja maupun dalam bentuk investasi, dibandingkan dengan pembiayaan konsumsi. Jumlah ini lebih besar dari setengah dari total pembiayaan perbankan syariah. Perputaran dana dari berbagai jenis usaha yang dilakukan oleh perbankan syariah ini semakin lama semakin meningkat, tetapi diiringi pula dengan peningkatan pembiayaan bermasalah.

Dilihat dari sisi jenis layanan Unit Usaha Syariah maupun Bank Umum Syariah, layanan yang paling banyak digunakan dalam pembiayaan UMKM adalah layanan mudharabah dan musyarakah. Pada Laporan yang sama (Statistik Perbankan Syariah), Kegiatan Usaha Bank Umum Syariah maupun Unit Usaha Syariah pada September 2016, pada layanan mudharabah, dan musyarakah mengalami kenaikan dari waktu ke waktu. Hal ini dapat dilihat dari perkembangan kedua jenis layanan tersebut, pada tabel 6 .

Tabel 6. Perkembangan Pembiayaan Mudharabah dan Musyarakah

\begin{tabular}{ccccccc}
\hline \multirow{2}{*}{ Pembiayaan } & \multicolumn{2}{c}{2014} & \multicolumn{2}{c}{2015} & \multicolumn{2}{c}{2016} \\
\cline { 2 - 7 } & Nov & Des & Nov & Des & Agust & Sept \\
\hline Mudharabah & 14.307 & 14.354 & 14.680 & 14.820 & 14.577 & 14.696 \\
\hline Musyarakah & 49.946 & 49.336 & 58.391 & 60.713 & 66.680 & 69.228 \\
\hline
\end{tabular}


Pada tabel di atas pembiayaan bagi hasil usaha (mudharabah) mengalami kenaikan dari posisi Desember 2014 sejumlah 14,354 triliun menjadi 14,820 triliun, dan menjadi 14,696 triliun pada tahun 2016. Begitu juga dengan pembiayaan musyarakah dari 49,336 pada Desember 2014, menjadi 60,713 triliun pada tahun 2015, kemudian meningkat menjadi 69, 228 triliun.

\section{Pentingnya Kemitraan Lembaga Keuangan Syariah dan UMKM}

Krisis moneter tahun 1997 silam menyadarkan banyak pihak betapa pentingnya pembangunan ekonomi berbasis usaha di sektor riil, yaitu sektor usaha yang nyata bergerak di tengah-tengah masyarakat, seperti pertanian, perdagangan tradisional, koperasi, industri kecil, dan seterusnya. Pembangunan tidak lagi diserahkan kepada para pemodal besar, melainkan kepada berbagai pihak, terutama Usaha Mikro, Kecil dan Menengah atau UMKM.

Selama ini UMKM sulit menerima bantuan di bidang permodalan. Ada beberapa hal kenapa modal dari bank konvensional lebih banyak didominasi oleh konglomerat:

Menjadi rahasia umum bahwa pengusaha yang dekat dengan kekuasaan (pengambil kebijakan publik) punya akses lebih mudah terhadap sumber permodalan, sehingga mengorbankan permodalan yang seharusnya ditujukan kepada pengusaha kecil dan menengah.

Modal sering dialokasikan kepada hal-hal yang bersifat non produktif dan non riil yang bermanfaat bagi orang banyak, melainkan kepada usaha-usaha spekulatif dalam jumlah milyaran rupiah, sehingga menyebabkan kehancuran sektor swasta di tahun 1997-1999 diakibatkan karenanya melonjaknya beban bunga tersebut. (Antonio: 2001: 79)

Pada masa itu, bank banyak mengalami kemunduran akibat kredit macet yang disebabkan karena banyaknya beban piutang yang tidak bisa dibayarkan akibat karena krisis moneter. Inilah yang menjadi dasar bagi pemerintah waktu itu dalam mengambil kebijakan untuk menggelontorkan dana bantuan likuiditas BLBI (Bantuan Likuiditas Bank Indonesia). Hal ini berbeda dengan lembaga keuangan syariah seperti BMT, yang mengeluarkan pembiayaan pada sektor riil pada UMKM. UMKM tahan dari krisis karena ada beberapa faktor, seperti UMKM dapat menghasilkan barang, konsumsi, dan jasa yang sangat dekat dengan kebutuhan masyarakat serta kemampuan UMKM dalam memanfaatkan sumberdaya lokal, seperti SDM, bahan baku, peralatan dan modal.

Pemberdayaan sektor UMKM selain menguntungkan kedua belah pihak, juga menguntungkan ideologi negara yang berpaham kerakyatan dan ketahanan nasional menghadapi krisis keuangan. Dengan pemberdayaan di sektor riil ini, maka produksi dan distribusi ekonomi akan meningkat dan dapat dinikmati secara merata dan nyata. Oleh karena itu, diperlukan lembaga keuangan yang mudah terjangkau oleh para pelaku usaha kecil. Di sinilah peran dari lembaga keuangan syariah diperlukan, yaitu menghimpun dana dari masyarakat dalam bentuk tabungan, lalu menyalurkannya dalam bentuk pinjaman atau modal.

Lembaga keuangan syariah memberlakukan sistem bagi hasil yang mana dalam sistem ini tidak memungkinkan meminjam untuk kebutuhan non usaha riil karena konsepsi pembiayaan mudharabah hanya dimungkinkan jika pihak peminjam 
membutuhkan modal untuk usaha. Dari usaha yang dikembangkan tersebut, menghasilkan laba, dan laba dari usaha tersebut dibagi sesuai dengan perjanjian (akad) yang telah disepakati bersama. Berdasarkan asumsi seperti ini, sistem bagi hasil ini tidak dapat diberlakukan kepada calon peminjam untuk memenuhi kebutuhan kebutuhan konsumtif, seperti SPP Sekolah apalagi sekedar untuk membeli baju untuk lebaran. Skema peminjaman ini bukan lewat skema pembiayaan mudharabah, tetapi melalui skema murabahah (akad jual beli) serta bisa juga dengan akad qardh al-hasan atau pinjaman murni non bagi hasil, dimana pengembalian hanya hutang pokok saja (Chapra, 2000: 9)

Lembaga keuangan syariah dewasa ini masih sekedar sebagai alternatif di masyarakat tetapi idealnya kedepannya harus menjadi sebagai solusi utama dalam pengentasan kemiskinan, peningkatan ekonomi masyarakat dan pemberdayaan UMKM. Lembaga keuangan syariah juga memegang prinsip keadilan dan kesetaraan antara lembaga yang memberikan pinjaman dengan para nasabahnya, berbeda dengan bank konvensional karena pinjaman bank konvensional memberlakukan bunga yang sama sekali tidak melihat bagaimana hasil usaha (laba) yang didapatkan oleh nasabah. Hal ini karena bank konvensional tidak menerapkan akad sistem bagi hasil. Selain itu, orientasi bank syariah tidak selalu profit oriented, melainkan untuk tujuan sosial. Kemampuan lembaga keuangan syariah dalam melayani sektor usaha riil inilah yang benar-benar dibutuhkan oleh pemerintah.

Kepercayaan lembaga keuangan (termasuk bank yang dimiliki oleh pemerintah) dalam memberikan kredit kepada pengusaha kecil tidaklah muncul berdasarkan ide kosong, tetapi didasarkan atas pengalaman. Di tingkat internasional, dimulai ketika Muhammad Yunus, seorang peraih Nobel Perdamaian, mendirikan bank khusus pembiayaan usaha kecil, lewat Grameen Bank. (Solihin, 2008: 257).

Dorongan melakukan pemberdayaan sektor UMKM olehlembaga keuangan syariah lebih besar daripada bank konvensional. Karena asas yang digunakan adalah nilai-nilai keislaman, dimana unsur pembelaan terhadap kaum lemah (mustadh'afin) lebih diutamakan. Selain itu ada cita-cita Islam yang perlu diperhatikan oleh penggiat ekonomi syariah, yaitu asas "likay laa duulatan baina aghniyaa-i minkum" yang berarti agar supaya harta tidak berputar diantara orang-orang kaya diantara kamu (Q.S. Al Hasyr: 7). Kedepan, pembiayaan terhadap usaha kecil kurang mampu, punya potensi untuk dikembangkan berdasarkan nilai-nilai keislaman tersebut.

Hal ini telah dilakukan oleh lembaga keuangan Islam. Sebagian dari lembaga keuangan syariah melakukan pengorganisasian pada beberapa kelompok usaha menengah ke bawah. Mereka mengorganisir peminjam dan memberikan bantuan pembiayaan lunak. Tujuannya untuk memperkuat kapasitas mereka dalam hal merencanakan usaha dalam skala mikro. Sehingga, LKS (Lembaga Keuangan Syariah) dapat berperan sebagai salah satu partner wirausaha kecil atau mikro, tidak hanya memberi bantuan modal ringan, tetapi juga melakukan pembinaan dan pemberdayaan sampai tingkat akar rumput.

Pada masa lampau, sebelum berkembangnya lembaga keuangan syariah yang melayani usaha kecil, berkembang praktek perkreditan dengan menggunakan metode pinjaman bersuku bunga sangat tinggi (berlipatganda), bahkan dihitung berlipat tiap pekannya. Praktek tersebut ada dalam masyarakat karena belum adanya lembaga 
keuangan yang dikelola secara profesional. Para rentenir ingin memastikan keuntungan (profit) yang jelas dan pasti, di sisi lainnya masyarakat banyak membutuhkan mereka.

Kehadiran lembaga keuangan syariah yang mudah diakses ditambah dengan kredit mikro yang diselenggarakan oleh pemerintah, misalnya program KUR (Kredit Usaha Rakyat), lambat laun akan mengurangi praktek rentenir ditengah tengah masyarakat. Sehingga di sini, terjadi kerjasama pihak pemerintah, BUMN dan swasta (termasuk lembaga keuangan syariah), untuk memberantas praktek lintah darat, sekaligus memberdayakan para pengusaha kecil dan mikro.

\section{PENUTUP}

Usaha Mikro Kecil Menengah (UMKM), sangat penting bagi perkembangan ekonomi di Indonesia karena kontribusi UMKM sangat jelas di sektor riil dan dilakukan oleh sekelompok akar rumput, dan sebagai salah satu tiang penyangga stabilitas ekonomi nasional. Sebagaimana dibuktikan oleh daya tahan UMKM terhadap krisis moneter pada tahun 1997 silam, bahwa lebih dari 95 persen sektor usaha ini mampu bertahan di tengah kolapsnya moneter nasional.

Karakteristik UMKM adalah beromzet relatif rendah, mempunyai peralatan seadanya (tradisional/manual), dan punya pangsa pasar lebih sempit. Mereka juga membutuhkan modal untuk mengembangkan usaha. Bidang inilah yang perlu diisi oleh lembaga keuangan syariah. Dimana dalam syariat Islam, sektor pembiayaan untuk usaha riil dipraktekkan secara langsung, baik oleh Rasulullah maupun oleh para sahabat Nabi, termasuk Sahabat Umar Ibn Khatab.

Pemberian pembiayaan kepada UMKM lebih efektif, karena dialokasikan benar-benar pada kebutuhan usaha kecil secara langsung. Pertimbangan lain yang harus diperhatikan oleh pemerintah adalah bahwa landasan filosofis negara ini adalah Pancasila. Dalam hal ini, negara berdasarkan atas Keadilan Sosial Bagi Seluruh Rakyat Indonesia.

Sebagaimana diketahui bahwa Indonesia menempati urutan keempat negara dengan ketimpangan terbesar di seluruh dunia, setelah Rusia, India, dan Thailand. Dengan pemberian pembiayaan kepada UMKM, maka diharapkan ketimpangan ini dapat diperkecil, sesuai dengan cita-cita para founding fathers negara ini.

\section{DAFTAR PUSTAKA}

Antonio, M.S. (2001). Bank Syariah: Dari Teori Ke Praktik. Jakarta: Gema Insani Press.

Chapra, M.U. (2000). Sistem Moneter Islam. Jakarta: Gema Insani Press.

Ikit. (2015). Akuntansi Penghimpunan Dana Bank Syariah. Yogyakarta: Deepublish.

Laksmana, Y. (2009). Tanya Jawab Cara Mudah Mendapatkan Pembiayaan Di Bank Syariah. Jakarta: Elex Komputindo.

Lewis, M. K. \& Algaoud, L. M. (2001). Perbankan Syariah: Prinsip, Pratik, dan Prospek. Jakarta: Serambi.

Sholihin, A.I. (2010). Buku Pintar Ekonomi Syariah. Jakarta: Gramedia

Solihin, A.I. (2008). Ini Lho, Bank Syariah. Jakarta: Hamdalah.

Wrihatnolo, R.R. \& Dwidjowijoto, R. N. (2007). Manajemen Pemberdayaan. Jakarta: Elex Media Komputindo. 
Muhammad, I.A.J. (2009). Tafsir Ath Thabari Vol. IV. Jakarta: Pustaka Azzam

UU No. 20 Tahun 2008 tentang Usaha Mikro Kecil dan Menengah

www.beritasatu.com

www.mandirisyariah.co.id 